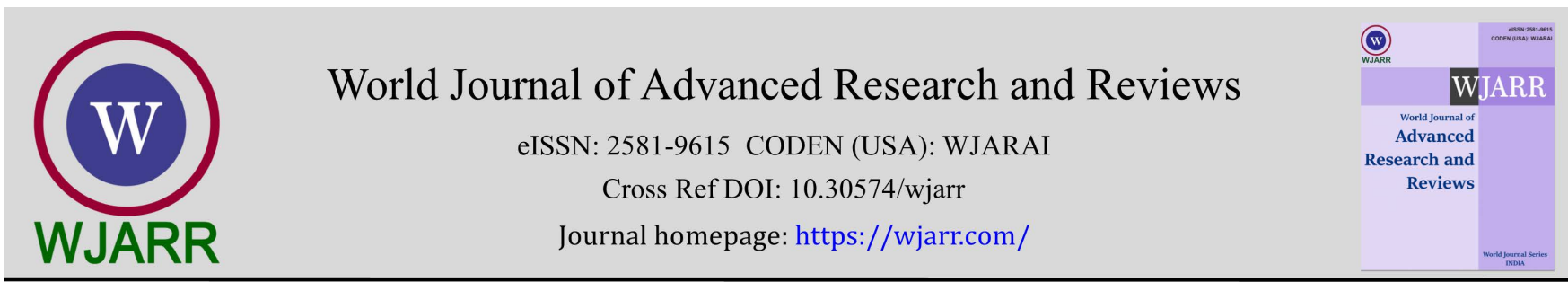

(RESEARCH ARTiClE)

\title{
The effect of two starter cultures on some chemical and sensory properties of Macedonian traditional sausage
}

\author{
Monika Stojanova ${ }^{1,}{ }^{*}$ and Dragutin Đukić ${ }^{2}$ \\ ${ }^{1}$ University of Ss. Cyril and Methodius, Faculty of Agricultural Sciences and Food, Aleksandar Makedonski blvd, Skopje, \\ North Macedonia. \\ 2 University of Kragujevac, Faculty of Agronomy, Cara Dušana 34, Čačak, Serbia.
}

World Journal of Advanced Research and Reviews, 2021, 09(03), 245-252

Publication history: Received on 07 February 2021; revised on 11 March 2021; accepted on 14 March 2021

Article DOI: https://doi.org/10.30574/wjarr.2021.9.3.0097

\begin{abstract}
The aim of this study is to monitor the effect of two starter cultures on some chemical and sensory properties of industrially produced Macedonian traditional sausage. The research covered three variants: Variant 1: Control variant (conventionally produced Macedonian traditional sausages using nitrite salt and powdered acerola); Variant 2: Macedonian traditional sausages where the basic formulation was enriched by addition of starter culture CS-300 (Staphylococcus carnosus ssp. utilis + Staphylococcus carnosus) in combination with Swiss chard powder and powdered acerola; Variant 3: Macedonian traditional sausages where the basic formulation was enriched by addition of starter cultures CS-300 (Staphylococcus carnosus ssp. utilis + Staphylococcus carnosus) and BLC-78 (Pediococcus acidilactici + Staphylococcus carnosus) in combination with Swiss chard powder and powdered acerola. Starter cultures have a positive effect on changing the $\mathrm{pH}$ value of sausages, which creates favorable conditions for the development of the desired microflora. In the sausages from variant 2 the value for water activity is constant, and the largest decrease was determined in the variant 3. Nitrate-reducing bacteria in combination with a natural source of nitrates (Swiss chard powder and leek) are a suitable substitute for nitrite salt, thus eliminating its negative effects on consumer health. According to the obtained results, with the use of the starter culture CS-300 good quality of the sausages is achieved. At the same time a safe product is obtained where the use of nitrite salt is completely eliminated.
\end{abstract}

Keywords: Traditional sausages; Starter cultures; Nitrites

\section{Introduction}

The production of the first sausages is thought to have taken place in ancient Greece, as evidenced by quotes from Homer who described sausages as a delicacy of minced meat and spices. Today, sausages belong to the largest group of meat products available in a wide range of types and with different commercial names. Numerous requests from consumers initiate the production of new types of sausages, with different composition and additives to improve their nutritional and health safety, in accordance with modern technological production processes [1].

The various canning procedures used in the meat industry have to extend the shelf life of meat and meat products over a period of time, ie to prevent their spoilage [2]. The application of various canning procedures aims at maximum preservation of the nutritional and sensory values of meat or meat products [3].

Nitrites belong to the group of preservatives, ie additives that prevent infection, intoxication and spoilage of sausages and meat products in general and increase their durability [4]. They also affect the change and achievement of numerous

\footnotetext{
${ }^{*}$ Corresponding author: Monika Stojanova

University of Ss. Cyril and Methodius, Faculty of Agricultural Sciences and Food, Aleksandar Makedonski blvd, Skopje, North Macedonia.
}

Copyright (C) 2021 Author(s) retain the copyright of this article. This article is published under the terms of the Creative Commons Attribution Liscense 4.0. 
quality properties of sausages, such as color, smell, taste, texture and so on. In the meat industry, they are most commonly used in the form of sodium nitrite (E250) and potassium nitrite (E249), or as sodium nitrate (E251) and potassium nitrate (E252) [5]. Nitrates, unlike nitrites, do not have antimicrobial activity, but with the action of nitratreductive bacteria, with the help of the enzyme nitrate-reductase, they are reduced to nitrites. Their concentration during the production process is significantly reduced, and thus they show antimicrobial effect, which is further contributed by the higher $\mathrm{pH}$ value [6].

The $\mathrm{pH}$ value of food has a great influence on the development and viability of microbial cells. Like any other factor, the $\mathrm{pH}$ value, in interaction with other factors such as water activity, the presence of salt, temperature, redox potential or the presence of preservatives, can stimulate or inhibit certain microbial species. The use of lactic acid bacteria in meat products results in their rapid acidification. The low $\mathrm{pH}$ value is directly correlated with the durability of the products [7]. Therefore, the appropriate $\mathrm{pH}$ value of sausages is of great importance for the proper growth and development of microorganisms that are naturally present in meat and all added additives, and especially for the proper direction of the activity of the used starter cultures [8].

The growing need for safe food that does not contain chemical additives, but also food that has the desired sensory characteristics, increases the interest in the application of starter cultures [9]. Such microorganisms possess at least one of the significant functional characteristics (organoleptic, nutritional and technological advantages or have a positive effect on consumer health) and therefore their use is a compromise between the requirements of consumers on the one hand and the food industry on the other [10].

Starter cultures are a large number of cells prepared in a special, microbiological way, usually from one type of microorganism, which added to the initial raw material leads to the formation of a fermented product by accelerating and controlling the fermentation process itself [8]. The use of certain types of microorganisms, as part of the starter cultures that produce components that are of great importance for the aroma of the product, results in a pleasant taste, as well as shortening the maturation time. Starter cultures, on the other hand, also control the decrease of the pH value of the environment, which enables inhibition of the growth of undesirable microorganisms, which increases the safety and stability of the final product [9].

The aim of this research is to monitor the effect of two starter cultures on some chemical and sensory properties of industrially produced Macedonian traditional sausage.

\section{Material and methods}

As a material for work was used Macedonian traditional sausage produced in industrial conditions in the meat industry "Soleta" in Skopje. As a basis for the production the traditional formulation of Vevcanski sausage was taken, modified for industrial use. Pork meat (I category) and dorsal bacon were used in the ratio 75:25\%. Water was added in an amount of $150 \mathrm{~g} / \mathrm{kg}$ mixture. Than additives, spices and starter cultures were added to the mixture. The following starter cultures were used: CS-300 (Staphylococcus carnosus ssp. utilis) and BLC-78 (Pediococcus acidilactici + Staphylococcus carnosus).

The research in this paper covered three variants:

- Variant 1: Control variant (conventionally produced Macedonian traditional sausages using nitrite salt and powdered acerola);

- Variant 2: Macedonian traditional sausages where the basic formulation was enriched by the addition of starter culture CS-300 in combination with powder Swiss chard (as a substitute for nitrite salt) and powdered acerola;

- Variant 3: Macedonian traditional sausages where the basic formulation was enriched by the addition of starter cultures CS-300 and BLC-78 in combination with powder Swiss chard (as a substitute for nitrite salt) and powdered acerola.

The meat and bacon were ground to pieces of $8 \mathrm{~mm}$. Then all spices and starter cultures were added, according to the determined formulation. The aim of adding Swiss chard powder is to provide a natural source of nitrates that the added starter cultures will convert into nitrites with which it is expected to achieve better results compared to the control variant where nitrite salt is added during production, and the only source nitrates is the leek that is part of the basic formulation. In this way, not only nitrite salt is completely excluded from use, thus eliminating its adverse effects on the health of consumers, but also improvements in the quality of sausages have been achieved. The meat, together with the 
added spices and starter cultures, was mechanically mixed in a stirrer. Then, the mixture was left to stand for 48 hours in a refrigerator at a temperature of $1-3^{\circ} \mathrm{C}$.

After leaving the mixture, it was accessed to machine filling of the sausages, where during the filling of the mixture of each variant, detailed washing and cleaning of the filler was carried out. Sausages were then thermally treated according to a program that was created according to the needs and modification of the basic formulation.

\subsection{Determination of the presence of residual nitrites}

The presence of residual nitrites was determined in the final product on the $1^{\text {st }}, 10^{\text {th }}$ and $20^{\text {th }}$ day of production. Three samples were randomly selected from each variant separately and analyzed according to the method of [12].

\subsection{Determination of $\mathrm{pH}$ value}

The $\mathrm{pH}$ value was determined by a portable pH meter (Mettler toledo FE20/F62) with a piercing, glass electrode for direct determination of the $\mathrm{pH}$ value in meat and meat products. Before and during the $\mathrm{pH}$ reading, the $\mathrm{pH}$ meter was calibrated with standard buffers ( $\mathrm{pH} 4.00$ and 7.00 at $20^{\circ} \mathrm{C}$ ). The results for the $\mathrm{pH}$ value are expressed as the arithmetic mean of the three measurements.

\subsection{Determination of water activity (Aw)}

The water activity was determined in the final product on the $1^{\text {st }}$ and $30^{\text {th }}$ day of the production, using the instrument Aw meter (Rotronic), and the obtained results are presented as an arithmetic mean of three analyzed samples taken at random from each variant separately.

\subsection{Sensory analysis}

The examination of the sensory characteristics is performed on the $7^{\text {th }}$ day of production. Assessment of the sensory properties of the prepared product was performed by comparison-scoring method [13]. The sensory optimal features were: color, smell, taste, consistency, cross-sectional appearance, outside look. The assessment is performed on a scale of 0 to 5 , where each grade represents a certain level of quality: grade 0 indicates a product with visible mechanical or microbiological damage; grade 1 indicates altered and atypical color or some other property of the product (unacceptable product); grade 2 indicates that the product has certain, significantly noticeable defects in quality; grade 3 indicates partially noticeable defects in quality; grade 4 indicates insignificant deviations in terms of color or some other property; and grade 5 indicates that the product has exceptional, characteristic sensory properties, optimal color, ie optimal overall quality. For each of the above mentioned characteristics, the coefficient of importance has been determined: outside look - 1; the cross-sectional appearance - 4; consistency - 3; color - 3; odor - 4; and taste - 5. The grade for each property is multiplied by the coefficient of importance. Values are collected and divided by the coefficients (20). The obtained value represents the weighted average value, ie the weighted value - general grade of the quality of the examined sausage. In addition, the percentage of the maximum possible quality is calculated, which represents the weighted average value (WAV) compared to the maximum value (5):

WAV / $5 \cdot 100$

All of the sensory parameters are rated on fresh sausage samples from each variant separately.

\subsection{Statistical analysis}

The obtained results were statistically processed using the software package SPSS 20. To determine the statistical significant differences of the obtained values, one-way analysis of variance (ANOVA test) was performed, followed by post hoc Tukey's test $(\mathrm{p}=.05)$ for analysis of values between variants.

\section{Results and discussion}

From the data presented in Table 1, can be seen that on the first day of production, sausages from variant 3 are characterized with the highest content of residual nitrites $(2.27 \mathrm{mg} / 100 \mathrm{~g})$, while the lowest value is observed in variant $2(1.46 \mathrm{mg} / 100 \mathrm{~g})$. The content of residual nitrites in the control variant in which nitrite salt $\left(0.5 \% \mathrm{NaNO}_{2}\right)$ was applied is $1.62 \mathrm{mg} / 100 \mathrm{~g}$. There is a statistically significant difference $(\mathrm{p}<0.05)$ in variant 2 and variant 3 compared to the control variant. There is a statistically significant difference $(\mathrm{p}<0.05)$ between variant 2 and variant 3 , too. 
Table 1 Residual nitrite content in sausages (mg/100g)

\begin{tabular}{|c|c|c|c|c|}
\hline \multirow[t]{2}{*}{ Variants } & \multirow[t]{2}{*}{$\mathbf{n}$} & $\begin{array}{l}1^{\text {st day of the }} \\
\text { production }\end{array}$ & $\begin{array}{l}10^{\text {th }} \text { day of the } \\
\text { production }\end{array}$ & $\begin{array}{l}30^{\text {th }} \text { day of the } \\
\text { production }\end{array}$ \\
\hline & & $\bar{x} \pm \mathrm{SD}$ & $\bar{x} \pm \mathrm{SD}$ & $\bar{x} \pm \mathrm{SD}$ \\
\hline Variant 1 & 3 & $1.62^{\mathrm{a}} \pm 0.02$ & $2.62^{\mathrm{a}} \pm 0.02$ & $3.45^{\mathrm{a}} \pm 0.03$ \\
\hline Variant 2 & 3 & $1.46^{b} \pm 0.02$ & $3.52^{b} \pm 0.02$ & $3.68^{b} \pm 0.01$ \\
\hline Variant 3 & 3 & $2.27^{c} \pm 0.02$ & $2.21^{\mathrm{c}} \pm 0.00$ & $4.61^{c} \pm 0.00$ \\
\hline
\end{tabular}

Furthermore, on the $10^{\text {th }}$ day of production, as a result of the activity and the number of nitrate-reducing bacteria that remained present in the sausages, the value of residual nitrites increased in the variant $2(3.52 \mathrm{mg} / 100 \mathrm{~g})$. On the other hand, in variant 3, a minimal reduction is observed $(2.21 \mathrm{mg} / 100 \mathrm{~g})$. In these two variants, as a substitute for nitrite salt, a natural source of nitrates was added by adding Swiss chard powder and leeks, which are further reduced to nitrites by the starter cultures added during the sausage production. Variant 2 and variant 3 are statistically significantly different $(p<0.05)$ from the control variant. Moreover, on the $20^{\text {th }}$ day of the production, there is a significant increase of the content of residual nitrites in variant 3 , in which two starter cultures were applied $(4.61 \mathrm{mg} / 100 \mathrm{~g})$. A small increase is also observed in variant 2 , in which one starter culture was added $(3.68 \mathrm{mg} / 100 \mathrm{~g})$. A tendency of minimal increasing is observed in the control variant, where on the $10^{\text {th }}$ day of production $2.62 \mathrm{mg} / 100 \mathrm{~g}$ nitrites are determined, while on the $20^{\text {th }}$ day of production this value increases to $3.45 \mathrm{mg} / 100 \mathrm{~g}$. There is statistically significant difference $(\mathrm{p}<0.05)$ in the variants 2 and 3 compared to the control variant.

The initial input of nitrites in the control variant in this research is $12.0 \mathrm{mg} / 100 \mathrm{~g}$, and their value in the finished product is significantly reduced due to the added acerola powder $(2 \mathrm{~g} / \mathrm{kg}$, which according to the declaration contains $25 \%$ vitamin C) which has a pronounced reducing effect on the content of residual nitrites after heat treatment of sausages.

The obtained data correspond to the research of Михајловиќ [14], where in the frankfurter in which ascorbic acid has been added, the content of residual nitrites in the $2^{\text {nd }}$ day after production is $6.87 \mathrm{ppm}$, ie their content is significantly reduced compared to the initial input of $12.0 \mathrm{mg} / 100 \mathrm{~g}$. Lila et al. [15] found that the residual nitrite content of frankfurter sausage produced from beef after heat treatment was $2.70 \mathrm{mg} / 100 \mathrm{~g}$. The initial nitrite input was 11.9 $\mathrm{mg} / 100 \mathrm{~g}$. Kovačević et al. [16] investigated the content of residual nitrites in different types of sausages available on the Croatian market. Namely, they pointed out that the content of residual nitrites in the long shelf life sausages was $0.70 \mathrm{mg} / 100 \mathrm{~g}$, while in heat-treated sausages it was $4.20 \mathrm{mg} / 100 \mathrm{~g}$. On the other hand, Bacus's [17] research by the Danish company ChrHansen indicates that using the starter culture CS-300 in the production of ham, the content of residual nitrites after heat treatment was $1.50 \mathrm{mg} / 100 \mathrm{~g}$, which is in line with the values obtained in this study in variant 2, in which the same starter culture was applied. Nevertheless, Merino et al. [18] found that in pork and beef sausages, on the $15^{\text {th }}$ day of production, the content of residual nitrites was $2.3 \mathrm{mg} / 100 \mathrm{~g}$, while on the $19^{\text {th }}$ day of production, their content increased to $2.8 \mathrm{mg} / 100 \mathrm{~g}$, and then the value decreased until the $45^{\text {th }}$ day of production when it was 0 $\mathrm{mg} / 100 \mathrm{~g}$.

The meat that was used as a raw material for the production of the Macedonian traditional sausage, has a pH value of 5.86 and a temperature value of $12^{\circ} \mathrm{C}$, which is in accordance with the necessary criteria (Table 2). Namely, according to Čavlek [19] for the production of semi-permanent sausages, it is best for the meat used as raw material to have a pH value between 5.4 and 5.8. This creates favourable conditions for further development of lactic acid bacteria which are expected to achieve the desired quality properties of the final product.

Table $2 \mathrm{pH}$ value and temperature of raw material (pork).

\begin{tabular}{|l|l|l|}
\hline \multirow{2}{*}{ Fresh pork meat } & pH value & Temperature $(\stackrel{\circ}{ } \mathrm{C})$ \\
\cline { 2 - 3 } & 5.86 & 12.00 \\
\hline
\end{tabular}

From the data presented in Table 3, it can be seen that in the filling of all three variants a minimal decrease in $\mathrm{pH}$ is observed. The lowest pH value of 5.76 is determined in the variant 3 (CS-300 + BLC-78), and the highest pH value is determined in the control variant. The minimal decrease in the $\mathrm{pH}$ value of the filling is primarily due to the added 
cultures and additives, but also to the initial activity of the starter cultures, which at this stage is still insignificant. A statistically significant difference $(\mathrm{p}<0.05)$ is found in variant 3 compared to the control variant.

Table 3 Average $\mathrm{pH}$ of the sausages.

\begin{tabular}{|c|c|c|c|c|c|c|}
\hline Variant & $\mathbf{n}$ & $\begin{array}{l}\text { Filling } \\
\text { hours } \\
\text { filling) }\end{array}$ & $\begin{array}{l}\text { Sausages } \\
\text { after heat } \\
\text { treatment }\end{array}$ & $\begin{array}{l}\text { Sausages - } \\
10^{\text {th day of }} \\
\text { the } \\
\text { production }\end{array}$ & $\begin{array}{l}\text { Sausages - } \\
30^{\text {th day of }} \\
\text { the } \\
\text { production }\end{array}$ & $\begin{array}{l}\text { Sausages - } \\
45^{\text {th }} \text { day of } \\
\text { the } \\
\text { production }\end{array}$ \\
\hline & & $\bar{x} \pm \mathrm{SD}$ & $\bar{x} \pm \mathrm{SD}$ & $\bar{x} \pm \mathrm{SD}$ & $\bar{x} \pm \mathrm{SD}$ & $\bar{x} \pm \mathrm{SD}$ \\
\hline Variant 1 & 3 & $5.83^{a} \pm 0.01$ & $5.95^{\mathrm{a}} \pm 0.00$ & $6.04^{\mathrm{a}} \pm 0.01$ & $6.07^{a} \pm 0.01$ & $6.10^{\mathrm{a}} \pm 0.04$ \\
\hline Variant 2 & 3 & $5.81^{\mathrm{a}} \pm 0.03$ & $5.95^{\mathrm{a}} \pm 0.00$ & $6.03^{\mathrm{a}} \pm 0.00$ & $6.08^{a} \pm 0.01$ & $6.09^{b} \pm 0.04$ \\
\hline Variant 3 & 3 & $5.76^{b} \pm 0.04$ & $5.95^{\mathrm{a}} \pm 0.00$ & $6.04^{\mathrm{a}} \pm 0.00$ & $6.13^{b} \pm 0.01$ & $6.19^{a} \pm 0.06$ \\
\hline
\end{tabular}

After the heat treatment of the sausages, uniformity of this parameter is achieved in all three variants (5.95). At this stage, the increase in $\mathrm{pH}$ is due to the reduction of the presence of lactic acid bacteria, which reached their maximum growth and effect during the initial phase of the heat treatment program. Furthermore, on the $10^{\text {th }}$ day of the production, all three variants show a continuous increasing. Based on the obtained data, after the heat treatment, as well as on the $10^{\text {th }}$ day of production, no statistically significant differences in the $\mathrm{pH}$ value between the three examined variants were determined. On the $30^{\text {th }}$ day of production, the highest $\mathrm{pH}$ value is determined in variant 3 (6.13), compared to the control variant (6.07) and variant 2 (6.08). A statistically significant difference $(p<0.05)$ is found in variant 3 compared to the control variant, as well as between variants 2 and 3 . On the $45^{\text {th }}$ day of production, the sausages from the variant 3 are characterized with the highest $\mathrm{pH}$ value (6.19), and the sausages from the variant 2 with the lowest (6.09). Therefore, it can be noticed that lactic acid bacteria are most rapidly inactivated in variant 3 , resulting in the highest $\mathrm{pH}$ value. The change of this parameter is also affected by the storage time of the product.

In their research, Medić et al. [20] found that during the storage of finished products produced with starter cultures, there is an increase in $\mathrm{pH}$ values. Namely, at the beginning of the production, they determined that the $\mathrm{pH}$ value of all tested variants is 5.58, while during the expiration measurements, the $\mathrm{pH}$ value increased to 5.95 in the variant in which the starter cultures Pediococcus pentosaceus, Staphylococcus carnosus and Staphylococcus xylosus were applied. From that point of view, Zdolec et al. [21] noticed that in the first days, traditionally produced sausages have an average $\mathrm{pH}$ of 5.90 while before the expiration date, this value increased to 6.03. According to Molly et al. [22] the acidification of meat products, which occurs as a result of the multiplication of lactic acid bacteria, has a number of positive effects, such as lowering the $\mathrm{pH}$, providing hygienic stability, obtaining the characteristic sour taste, coagulation of proteins in meat, reducing the ability to water binding and development of the desired red color by favouring the reaction between nitrogen monoxide and myoglobin.

Table 4 Average values for water activity in the sausages.

\begin{tabular}{|l|l|l|l|}
\hline \multirow{2}{*}{ Variant } & \multirow{2}{*}{$\mathbf{n}$} & $\mathbf{1}^{\text {st }}$ day of the production & $\mathbf{3 0}^{\text {th }}$ day of the production \\
\cline { 3 - 4 } & & $\bar{x} \pm \mathrm{SD}$ & $\bar{x} \pm \mathrm{SD}$ \\
\hline Variant 1 & 3 & $0.919^{\mathrm{ab}} \pm 0.00$ & $0.906^{\mathrm{a}} \pm 0.00$ \\
\hline Variant 2 & 3 & $0.918^{\mathrm{a}} \pm 0.00$ & $0.918^{\mathrm{b}} \pm 0.00$ \\
\hline Variant 3 & 3 & $0.921^{\mathrm{b}} \pm 0.00$ & $0.896^{\mathrm{c}} \pm 0.00$ \\
\hline
\end{tabular}
a,b,c - values marked with different letters have a statistically significant difference between the examined variants $(\mathrm{p}<0.05)$.

From the data shown in Table 4, it can be seen that on the $1^{\text {st }}$ day of the production, the values for Aw differ minimally between the variants. The highest Aw value is determined in the samples from the variant $3(0.921)$, while the lowest value is obtained in the samples from variant $2(0.918)$. Statistically significant difference $(\mathrm{p}<0.05)$ is determined only between variant 2 and variant 3. During the storage of sausages, the content of available water decreases, which create conditions for inhibition of certain microbial communities, but on the other hand it also affects the sensory properties of the sausages. Therefore, based on the measurement of Aw on the $30^{\text {th }}$ day of the production, it can be seen that the highest reduction in the content of available water is determined in the sausages from variant 3 (0.896). A smaller 
difference is observed in the sausages from the control variant (0.906). Also, a statistically significant difference $(\mathrm{p}<0.05)$ is found in variants 2 and 3 compared to the control variant, as well as between variant 2 and variant 3 .

According to Pidcock et al. [23], compared to fresh meat, whose average value for Aw is 0.99 , the lower values for this parameter in sausages, allow them to be stored for a longer period. In their research, Medić et al. [20] found that in the variant in which the starter cultures Pediococcus pentosaceus, Staphylococcus carnosus and Staphylococcus xylosus were applied, on the $1^{\text {st }}$ day of production, the water activity was 0.958 while on the $40^{\text {th }}$ day this value decreased to 0.850 . According to authors, the evaporation of water also conditions the change of the primary chemical composition of the sausages. In comparison, Ciuciu et al. [24] pointed out that in sausages where the lactic acid bacteria Lactobacillus sakei was used as a starter culture, the initial value of water activity decreased from 0.962 to 0.827 in the final product.

According to the data in Table 5, it can be noticed that on the $7^{\text {th }}$ day of production, the sausages from the variant 3 are characterized with the highest marks for most of the examined properties (color, taste, consistency and cross-sectional appearance). The odor property is rated with the highest marks in variant 2 , while the outside look has the highest marks in the sausages from variant 1 . According to these results, the sausages from the variant 3 are characterized by statistically significant highest weighted average value (4.59) and highest \% of maximum possible quality (91.80\%).

Table 5 Average values from the sensory analysis of the sausages performed on the 7th day of production.

\begin{tabular}{|c|c|c|c|c|c|c|c|c|}
\hline \multirow{3}{*}{ Sensory properties } & \multirow{3}{*}{$\mathrm{n}$} & \multirow{3}{*}{$\mathrm{CI}$} & \multicolumn{2}{|c|}{ Variant 1} & \multicolumn{2}{|c|}{ Variant 2} & \multicolumn{2}{|c|}{ Variant 3} \\
\hline & & & \multirow{2}{*}{0} & $\mathrm{~K}$ & \multirow{2}{*}{0} & $\mathrm{~K}$ & \multirow{2}{*}{0} & K \\
\hline & & & & $\bar{x} \pm \mathrm{SD}$ & & $\bar{x} \pm \mathrm{SD}$ & & $\bar{x} \pm \mathrm{SD}$ \\
\hline Color & 20 & 3 & 4.41 & $13.23^{\mathrm{a}} \pm 0.01$ & 4.25 & $12.75^{\mathrm{b}} \pm 0.01$ & 4.73 & $14.19^{c} \pm 0.01$ \\
\hline Smell & 20 & 4 & 3.83 & $15.32^{\mathrm{a}} \pm 0.01$ & 4.33 & $17.32^{\mathrm{b}} \pm 0.03$ & 4.30 & $17.20^{c} \pm 0.01$ \\
\hline Taste & 20 & 5 & 3.83 & $19.15^{\mathrm{a}} \pm 0.01$ & 4.33 & $21.65^{b} \pm 0.03$ & 4.60 & $23.00^{c} \pm 0.04$ \\
\hline Consistency & 20 & 3 & 4.08 & $12.24^{\mathrm{a}} \pm 0.03$ & 4.00 & $12.00^{\mathrm{a}} \pm 0.21$ & 4.59 & $13.77^{\mathrm{b}} \pm 0.03$ \\
\hline $\begin{array}{l}\text { Cross-sectional } \\
\text { appearance }\end{array}$ & 20 & 4 & 4.41 & $17.64^{\mathrm{a}} \pm 0.03$ & 4.33 & $17.32^{\mathrm{b}} \pm 0.02$ & 4.73 & $18.92^{\mathrm{c}} \pm 0.02$ \\
\hline Outside look & 20 & 1 & 4.83 & $4.83^{\mathrm{a}} \pm 0.00$ & 4.50 & $4.50^{\mathrm{b}} \pm 0.04$ & 4.81 & $4.81^{\mathrm{a}} \pm 0.01$ \\
\hline Total CI & & 20 & & & & & & \\
\hline PSV & & & & $4.12^{\mathrm{a}} \pm 0.03$ & & $4.28^{\mathrm{b}} \pm 0.01$ & & $4.59 c \pm 0.09$ \\
\hline $\begin{array}{l}\% \text { of maximum } \\
\text { possible quality }\end{array}$ & & & & $82.40^{\mathrm{a}} \pm 0.71$ & & $85.60^{\mathrm{b}} \pm 0.61$ & & $91.80^{c} \pm 1.71$ \\
\hline
\end{tabular}
$\mathrm{a}, \mathrm{b}, \mathrm{c}, \mathrm{d}$ - values marked with different letters have a statistically significant difference between the examined variants $(\mathrm{p}<0.05)$.

The quality properties of food are a set of characteristics that are acceptable to consumers. They are divided into external factors (size, shape, color, consistency, odor, taste, texture) and internal factors (chemical, physical and microbiological) [25]. The way food is produced has a great influence on sensory characteristics. It is known that the typical taste and aroma of sausages produced with the addition of starter cultures, as the main sensory characteristics, is due to the activity of microorganisms and metabolic processes of decomposition of carbohydrates, proteins and lipids in meat, in combination with various spices [8,26]. Operta et al. [27] investigated the sensory characteristics of Bosnian sausage produced from fresh, chilled beef (type A) and frozen beef (type B), adding starter cultures Lactobacillus, Pediococcus, Staphylococcus and Candida. They found that both types of sausages have similar sensory properties. There were statistically significant differences in the mean for the cross-sectional appearance. Type B sausages had better consistency (7.55) compared to type A sausages (5.76), lighter color (6.13/7.79) and whiter adipose tissue color $(1.73 / 4.30)$. Furthermore, Toldrá [28] wrote that the ingrained taste of sausages as well as the yellowish color of adipose tissue occurs as a result of oxidation of unsaturated fatty acids. According to the results of sensory analysis of perennial sausages from domestic and wild boar obtained by Kos et al. [29], it is concluded that home-made pork sausages have a more intense smell, greater spiciness, as well as greater consistency and better overall quality. Nevertheless, Petrović et al. [30] pointed that the highest sensory rating for the overall appearance, had the sausages 
produced in the first season that were smoked and dried in traditional conditions. The lowest sensory rating for the overall quality was given to the sausages that were smoked and dried in industrial conditions.

\section{Conclusion}

Based on the analysis, it can be concluded that starter cultures have positive effect on changing the pH value of sausages, which creates favorable conditions for the development of the desired microflora. Moreover, in the sausages from variant 2 (CS-300) the value for water activity is constant, and the largest decrease is determined in the variant 3 (CS$300+$ BLC-78). Nitrate-reducing bacteria in combination with a natural source of nitrates (Swiss chard powder and leek) are a suitable substitute for nitrite salt, thus eliminating its negative effects on consumer health. Starter cultures have also a positive influence on the sensory properties in the industrially produced Macedonian traditional sausage. According to this research, with the use of the starter culture CS-300 (Staphylococcus carnosus ssp. utilis) good quality of the sausages is achieved. At the same time a safe product is obtained where the use of nitrite salt is completely eliminated.

\section{Compliance with ethical standards}

\section{Disclosure of conflict of interest}

Authors declare there is no conflict of interest.

\section{Statement of ethical approval}

The present research work does not contain any studies performed on animals/humans subjects by any of the authors.

\section{References}

[1] Hammes WP, Hertel C. New developments in meat starter cultures. Meat science. 1998; 49: 125-138.

[2] Leroy F, Verluyten J, De Vuyst L. Functional meat starter cultures for improved sausage fermentation. International Journal of Food Microbiology. 2006; 106: 270-285.

[3] Honikel KO. The use and control of nitrate and nitrite for the processing of meat products. Meat Science. 2008; 78: 1-2 68-76.

[4] Sebranek GJ, Bacus NJ. Cured meat products without direct addition of nitrate or nitrite, what are the issues?. Meat Science. 2007; 77: 136-147.

[5] Toldrá F. Handbook of Meat Processing. Wiley-Blackwell. 2121 State Avenue, Ames, Iowa 50014-8300, USA. 2010.

[6] Tompkin RB. Nitrite. In: Antimicrobials in Food. P. Michael Davidson, John n. Sofos, A. L. Branen. Taylor and Francis group. 2005; 169-236.

[7] Ђукић Д, Мандић Л, Весковић С. Општа и индустријска микробиологија. Универзитет у Крагујевцу, Агрономски Факултет, Чачак. 2015.

[8] Весковић МС, Ђукић Д. Биопротектори у производњи хране. Универзитет у Крагујевцу, Агрономски факултет, Чачак. 2015.

[9] Ђукић Д, Мандић Л. Технологија микробиолошких производа. ИП „Просвета“, Белград. 2012.

[10] Casaburi A, Aristoy MC, Cavella S, Di Monaco R, Ercolini D, Toldrá F, Villani F. Biochemical and sensory characteristics of traditional fermented sausages of Vallo di Diano (Southern Italy) as affected by the use of starter cultures. Meat Science. 2007; 76(2): 295-307.

[11] Zara M, Ionescu A, Vasile A, Aprodu I, Manoliu I. How starter cultures affect the sensorial characteristic and the microbiota evolution of dry sausages. Scientific Study \& Research, ISSN 1582-540X. 2007; VIII (4): $379-390$.

[12] Zambeli. Meat and meat products - determination of nitrite content (reference method), ISO 3091.1975.

[13] Radovanović R, Popov-Raljić J. Senzorna analiza prehrambenih proizvoda. Poljoprivredni fakultet, Beograd, Tehnološki fakultet, Novi Sad. 2001. 
[14] Михајловиќ И. Можности за намалување на содржината на резидуалните нитрити во реновките. Магистерски труд, УКИМ, Скопје. 2000.

[15] Lila H, Hill NB, Webb N, Delores M, Anams AT. Changes in residual nitrite in sausage and luncheon meat products during storage. J. Milk Food Technol. 1973; 36(10): 515-519.

[16] Kovačević D, Mastanjević K, Ćosić K, Pleadin J. Količina nitrita i nitrata u mesnim proizvodima s hrvatskog tržišta. Meso, No. 2 (XVIII). 2016; 40-46.

[17] Bacus J. Natural Ingredients for Cured and Smoked Meats, Chr. Hansen Inc. 59th Reciprocal Meats Conference, Gainesville, Florida. 2006.

[18] Merino L, Damerud PO, Toldra F, Ilback NG. Time-dependent depletion of nitrite in pork/beef and chicken meat products and its effect on nitrite intake estimation. Food Addit Contam Part A Chem Anal Control Expo Risk Assess. 2016; 33(2): 186-192.

[19] Čavlek B. Starter cultures in production of fermented meat products. Procedeening Moderne tehnologije predelave in kakovost živil 18, Bitenčevi živilski dnevi, Ljubljana, Slovenia. 1997; 137-151.

[20] Medić H, Vidaček S, Marušić N, Šatović V, Nežak J. Utjecaj ovitka i starter kultura na kvalitetu fermentiranih kobasica. Meso. 2009; 11: 113-122.

[21] Zdolec N, Hadžiosmanović M, Kozačinski L, Cvrtila Ž, Filipović I, Leskovar K, Vragović N, Budimir D. Fermentirane kobasice proizvedene u domaćinstvu - mikrobiološka kakvoća. Meso, Vol. IX studeni - prosinac br. 2007; 6: 318324.

[22] Molly K, Demeyer D, Johansson G, Raemaekers M, Ghistelinek M, Geenen I. The importance of meat enzymes in ripening and flavor generation in dry fermented sausages. First results of a European project. Food Chemistry. 1997; 59: 539-545.

[23] Pidcock K, Heard GM, Henriksson A. Application of nontraditional meat starter cultures in production of Hungarian salami. Int. J. of Food Microbiol. 2002; 76: 75-81.

[24] Simion Ciuciu AM, Carballo J, Alexe P. Microbiological evolution of Dacia sausage, a dry cured Romanian sausage. Chemistry and Chemical Engineering, Biotechnology, Food Industry. 2011; 12 (3): 215 - 220.

[25] Ruiz Pérez-Cacho MP, Gálan-Soldevilla H, León Crespo F, Molina Recio G. Determination of the sensory attributes of a Spanish dry-cured sausage. Meat science. 2005; 71: 620-633.

[26] Pleadin J, Vahčić N, Perši N, Kovačević D. Varijabilnost fizikalno-kemijskih i senzorskih svojstava autohtonih mesnih proizvoda između proizvodnih domaćinstava. Meso. 2013; 15: 122-131.

[27] Operta S, Dževdetbegović M, Čorbo S, Tahmaz J, Šehović A. Fizičko-hemijska i senzorna svojstva bosanskog sudžuka proizvedenog u kontrolisanim uslovima od svežeg ohlađenog i zamrznutog goveđeg mesa. Tehnologija mesa, UDK: 637.525'62.053/.055. 2012; 148-156.

[28] Toldrá F. Dry-cured meat products. Food \& Nutrition press, INC. USA. 2002.

[29] Kos I, Gredičak M, Sinčič Pulič B, Širič I, Mrkonjič Fuka M. Senzorna svojstva trajnih kobasica od mesa domaće i divlje svinje. 50th Croatian and 10th International Symposium on Agriculture, Proceedings, Opatija, Croatia. $2015 ; 438-442$.

[30] Petrović Lj, Džinić N, Tomović V, Ikonić P, Tasić T. Tehnološki Elaborat o načinu proizvodnje i specifičnim karakteristikama proizvoda Petrovská klobása (Petrovačka kobasica). Rešenje o registraciji oznake geografskog porekla Petrovská klobása (Petrovačka kobasica) kao imena porekla za suvomesnati proizvod fermentisanu kobasicu, broj: 9652/06 Г-03/06, Zavod za intelektualnu svojinu, Srbija. 2007. 